\title{
Obesity increases the incidence of 7,12- dimethylbenz $(a)$ anthracene-induced mammary tumors in an ovariectomized Zucker rat model
}

\author{
REZA HAKKAK ${ }^{1,2,3,4}$, STEWART MacLEOD ${ }^{4,5}$, SAEID SHAAF $^{1,3}$, ANDY W. HOLLEY ${ }^{1,3}$, PIPPA SIMPSON ${ }^{2,3}$, \\ GEORGE FUCHS $^{2,3}$, CHAN HEE JO ${ }^{2,3}$, THOMAS KIEBER-EMMONS ${ }^{4,5}$ and SOHEILA KOROURIAN ${ }^{4,5}$ \\ Departments of ${ }^{1}$ Dietetics and Nutrition, and ${ }^{2}$ Pediatrics, University of Arkansas for Medical Sciences, \\ 4301 W. Markham St; ${ }^{3}$ Arkansas Children's Hospital Research Institute, 1120 Marshall Street, \\ Little Rock, AR 72202; ${ }^{4}$ Arkansas Cancer Research Center, and ${ }^{5}$ Department of Pathology, \\ University of Arkansas for Medical Sciences, 4301 W. Markham St., Little Rock, AR 72205, USA
}

Received October 4, 2006; Accepted November 30, 2006

\begin{abstract}
Obesity is associated with increased risk for postmenopausal, but not premenopausal breast cancer. Recently, we reported that intact obese Zucker rats had increased susceptibility to DMBA-induced mammary tumors compared to lean Zucker rats. In the present study, we investigated whether excessive adipose tissue would promote mammary tumor induction in the absence of ovarian estrogen. Lean and obese rats were sham-operated or ovariectomized at 40 days old and were gavaged at 50 days old with $65 \mathrm{mg} / \mathrm{kg}$ DMBA. Rats were weighed and palpated twice weekly for detection of mammary tumors and sacrificed 135 days post-DMBA treatment. Obese sham-operated $(\mathrm{O} / \mathrm{S})$ rats had a shorter latency period (102 days) compared to lean sham-operated (L/S) (134 days) and obese ovariectomized (O/O) rats (123 days). At the end of the experiment, $36 \%$ of the $\mathrm{O} / \mathrm{O}$ rats developed mammary tumors while lean ovariectomized $(\mathrm{L} / \mathrm{O})$ rats developed no mammary tumors $(\mathrm{P}<0.001)$, and $59 \%$ of the $\mathrm{O} / \mathrm{S}$ rats developed mammary tumors compared to $30 \%$ of the $\mathrm{L} / \mathrm{S}$ rats $(\mathrm{P}<0.05)$. In summary, obesity increases the susceptibility of ovariectomized Zucker rats to DMBAinduced mammary tumors, suggesting that adipose tissuederived estrogen in obese animals may be sufficient to promote DMBA-induced tumors in this model. These results suggest that obesity in postmenopausal women may increase breast cancer risk due to increased breast tissue exposure to adipose tissue-derived estrogen. In conclusion, we have developed an animal model to further investigate the role of obesity in breast cancer development in postmenopausal women.
\end{abstract}

Correspondence to: Dr Reza Hakkak, Department of Dietetics and Nutrition, University of Arkansas for Medical Sciences, 4301 W. Markham St., Mail Slot 627, Little Rock, AR 72205, USA E-mail: hakkakreza@uams.edu

Key words: obesity, Zucker rats, DMBA-induced mammary tumors

\section{Introduction}

The rate of obesity has doubled in the United States in the past two decades, and obesity is now an epidemic. In addition to the relationship to Type 2 diabetes mellitus, obesity is also associated with development of several other serious health conditions, including cardiovascular diseases, hypertension, stroke, and certain types of cancer including breast cancer (1-3). The relationship between obesity and the development of specific cancers, including renal cell carcinoma and esophageal and colorectal cancers, has been well documented (4).

Breast cancer is the second leading cause of death from cancer in women in the US. The American Cancer Society estimated that during 2006, 212,920 women will be diagnosed with new cases of breast cancer and that 40,970 women will die from this disease (5). Increasing body weight has been associated with increased risk for postmenopausal, but not premenopausal breast cancer (6). Many clinical and pathologic characteristics of breast cancer place certain women at increased risk of poorer outcome, varying among ethnic groups. Possible explanations for the differential prognoses, such as differences in body weight, treatment, diet, genetics, estrogen level or estrogen receptor and hormonal status, continue as avenues of exploration $(7,8)$.

In the Nurses Health Study, women gaining more than $9 \mathrm{~kg}$ from 18 years of age to midlife doubled their risk for breast cancer, compared with women who maintained a stable weight (9). For example, the risk increases by $3 \%$ for each $\mathrm{kg} / \mathrm{m}^{2}$ increase in BMI (10). A recent large population-based cohort study of more than 145,000 Austrian women that examined the relationship between overweight, obesity and cancer found that the incidence of breast cancer was positively associated with high BMI only after 65 years of age (11). The pathogenesis of obesity and its relationships to breast cancer, however, have not yet been identified. Higher levels of circulating estrogen that have been attributed to elevated aromatase activity in expanded adipose tissue deposits have been cited as a potential contributing factor (12). The Women's Health Initiative clinical trial confirmed that hormone therapy 
Table I. Body and liver weights of sham and ovariectomized lean and obese Zucker rats.

\begin{tabular}{lcccc}
\hline & $\mathrm{L} / \mathrm{S}$ & $\mathrm{L} / \mathrm{O}^{\mathrm{a}}$ & $\mathrm{O} / \mathrm{S}^{\mathrm{b}}$ & $\mathrm{O} / \mathrm{O}^{\mathrm{c}}$ \\
\hline $\mathrm{n}$ & 30 & 31 & 27 & 25 \\
Body weight & & & & $167 \pm 2.76^{\mathrm{d}}$ \\
Initial & $107 \pm 1.85$ & $101 \pm 1.51^{\mathrm{d}}$ & $507 \pm 9.55^{\mathrm{d}}$ & $562 \pm 8.78^{\mathrm{d}}$ \\
Final & $287 \pm 5.02$ & $340 \pm 3.55^{\mathrm{d}}$ & & \\
Liver & & & $38.18 \pm 0.87^{\mathrm{d}}$ & $3.52 \pm 0.91^{\mathrm{d}}$ \\
Absolute & $8.24 \pm 0.16$ & $7.50 \pm 0.14^{\mathrm{d}}$ & $7.70 \pm 0.26^{\mathrm{d}}$ & $7.05 \pm 0.55^{\mathrm{d}}$ \\
Relative & $2.90 \pm 0.03$ & $2.20 \pm 0.03^{\mathrm{d}}$ & & \\
\hline
\end{tabular}

$\mathrm{L} / \mathrm{S}$, lean sham-operated; L/O, lean ovariectomized; $\mathrm{O} / \mathrm{S}$, obese sham-operated; and $\mathrm{O} / \mathrm{O}$, obese ovariectomized. Body weights and liver weights (absolute weights) are given in grams; organ weight to body weight ratios are given as grams of organ weight/grams of body weight as a percentage (mean \pm standard error). ${ }^{a} \mathrm{~L} / \mathrm{S}$ versus $\mathrm{L} / \mathrm{O}$. ${ }^{\mathrm{b}} \mathrm{L} / \mathrm{S}$ versus $\mathrm{O} / \mathrm{S}$. ${ }^{\mathrm{c}} \mathrm{L} / \mathrm{O}$ versus $\mathrm{O} / \mathrm{O} .{ }^{\mathrm{d}} \mathrm{P}<0.001$ (Fisher's exact test).

containing progestin is associated with increased risk of breast cancer in postmenopausal women. Other studies have implicated elevated circulating estrogen levels to be responsible for this increased risk $(13,14)$.

Several serum growth factors that are associated with increased body weight are also implicated in breast cancer risk. Higher insulin levels are associated with obesity and may enhance cellular proliferation leading to the development of breast cancer (15). Leptin is another serum growth factor that is positively associated with body weight or body fat $(16,17)$. Leptin has been shown to upregulate aromatase activity in breast cancer cells which results in increased estrogen levels, thereby stimulating proliferation (18). A positive association has been suggested between high serum insulin levels and poor breast cancer outcome due to increased leptin production by adipose tissue (19).

In animal models, higher body weight has been associated with increased incidence of both spontaneous and chemically induced mammary tumors (20-23). The obese Zucker ( $f a / f a)$ rat $(24,25)$ is an ideal animal model to investigate the role of obesity on chronic disease development. Obesity in the Zucker rat is caused by a mutation in the leptin receptor gene $(26,27)$. Obese Zucker $(f a / f a)$ rats are known to develop hyperinsulinimia and become insulin resistant. They are an ideal model to investigate the effects of genetic obesity and non-insulin-dependent diabetes mellitis on other chronic disease development such as cancer (28-30). The most valuable contribution of the Zucker rat has been its utility as a model of human early-onset, hyperplastic-hypertrophic obesity. In contrast to obese Zucker ( $f a / f a$ ) rats, lean Zucker rats have normal metabolic function and are ideal controls.

Lifetime estrogen exposure is a major risk factor in human breast cancer development. In postmenopausal women, the most important source of estrogen is from precursors synthesized in adipose tissue. Recently, we reported that obesity increased the rate of DMBA-induced mammary tumor development in intact female Zucker rats (31). In order to determine whether estrogens derived from adipose tissue are sufficient to promote mammary tumor development in the
DMBA-induced rat model, we used ovariectomized Zucker rats as a model to compare the rate of mammary tumor development in the presence and absence of ovarian estrogen in obese and lean Zucker rats.

\section{Materials and methods}

Experimental design. All animal protocols were approved by the Institutional Animal Care and Use Committee (IACUC) at the University of Arkansas for Medical Sciences. Female Zucker rats were sham-operated (lean, $\mathrm{n}=30$; obese $\mathrm{fa} / \mathrm{fa}$, $\mathrm{n}=27$ ) or ovariectomized (lean, $\mathrm{n}=31$; obese $\mathrm{fa} / \mathrm{fa}, \mathrm{n}=25$ ) at the age of 40 days by Harlan Industries (Indianapolis, IN). The animals were housed at animal facilities at the Arkansas Children's Hospital Research Institute, two per cage in polycarbonate cages and allowed ad libitum access to water and a semi-purified AIN-93G diet (Teklad, Madison, WI), as was reported previously (32). At the age of 50 days, all rats received via gavage $65 \mathrm{mg} / \mathrm{kg}$ DMBA (Sigma Chemical Co., St. Louis, MO) as previously reported (31). Rats were weighed twice weekly and were palpated for mammary tumor detection (twice weekly) beginning 2 weeks after DMBA treatment. Rats with tumor masses exceeding $2.5 \mathrm{~cm}$ in diameter were sacrificed early for humane reasons according to our IACUCapproved animal protocol. Rats were sacrificed 135 days postDMBA treatment. All mammary tumors were excised, counted and weighed. Tumor sections were placed in $10 \%$ neutral buffered formalin and sections $(5 \mu \mathrm{m})$ of the paraffin embedded tumors were stained with hematoxylin and eosin for histological analysis.

Pathology. All tumors were evaluated as previously reported (31) in a blinded protocol and were classified as benign or intraductal proliferation (IDP) as shown by multiple papillomas or with ductal hyperplasia, ductal carcinoma in situ (DCIS) or invasive ductal and lobular carcinoma (IDC).

Statistical analysis. A Kaplan-Meier analysis of tumor latency was performed $(33,34)$. A generalized Wilcoxon log-rank 

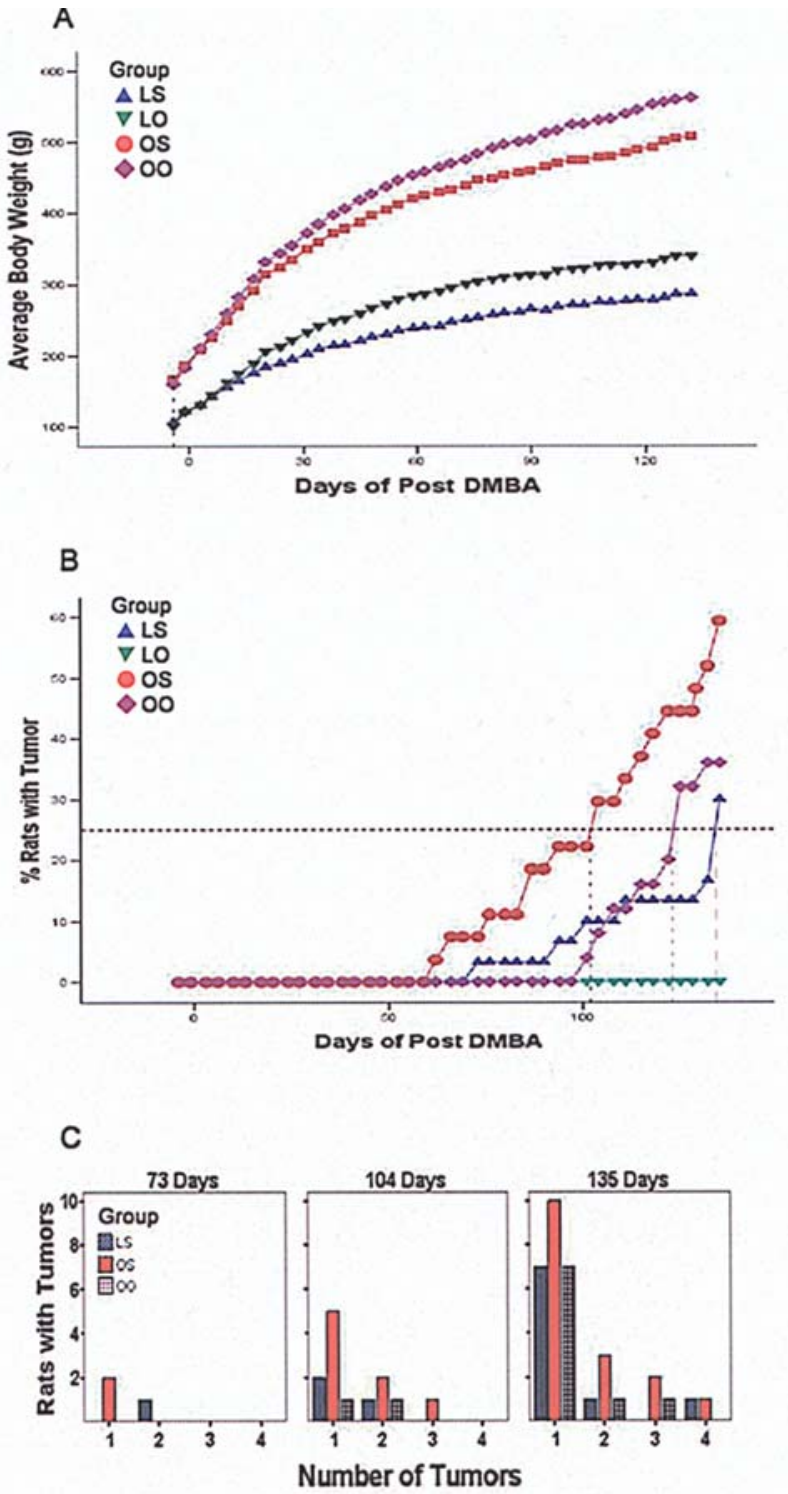

Figure 1. Body weights and mammary tumor incidence and multiplicity in DMBA-treated rats. (a) Body weights of $\mathrm{L} / \mathrm{S}(\mathrm{n}=30), \mathrm{L} / \mathrm{O}(\mathrm{n}=31), \mathrm{O} / \mathrm{S}$ $(n=27)$ and $\mathrm{O} / \mathrm{O}(\mathrm{n}=25)$ female rats following oral gavage of $65 \mathrm{mg} / \mathrm{kg}$ DMBA at 50 days of age (study day 0 ). (b) Mammary tumor incidence (percentage of rats with tumors) in female rats. Dashed lines indicate the post-DMBA days at which $25 \%$ of the $\mathrm{O} / \mathrm{S}, \mathrm{O} / \mathrm{O}, \mathrm{L} / \mathrm{S}$ and $\mathrm{L} / \mathrm{O}$ rats developed at least one mammary tumor. (c) Mammary tumor multiplicity in $\mathrm{O} / \mathrm{S}, \mathrm{O} / \mathrm{O}, \mathrm{L} / \mathrm{S}$ and $\mathrm{L} / \mathrm{O}$ rats at 73,104 and 135 days post-DMBA treatment.

test (35) was used to compare median tumor-free times. A Chi-square test (36) was used to compare percentage of animals with tumors in each treatment group for each experiment. Where the sample was small, a Fisher's exact test (36) was performed. The median numbers of tumors per tumor-bearing rat (multiplicity) for each group were compared using the nonparametric Kruskal-Wallis test (37). The total tumor volume and weight for each rat were calculated and compared for each group using also the Kruskal-Wallis test. Statistical significance was set at $\mathrm{P}<0.05$, and all $\mathrm{P}$ values were unadjusted for multiple comparisons. For the few rats that were sacrificed early due to tumor burden, we assumed that the number of tumors remained constant until the end of the study. Data analyses were generated and plots were constructed using SPSS(c) version 13.0 for Windows (SPSS Inc., Chicago, IL).
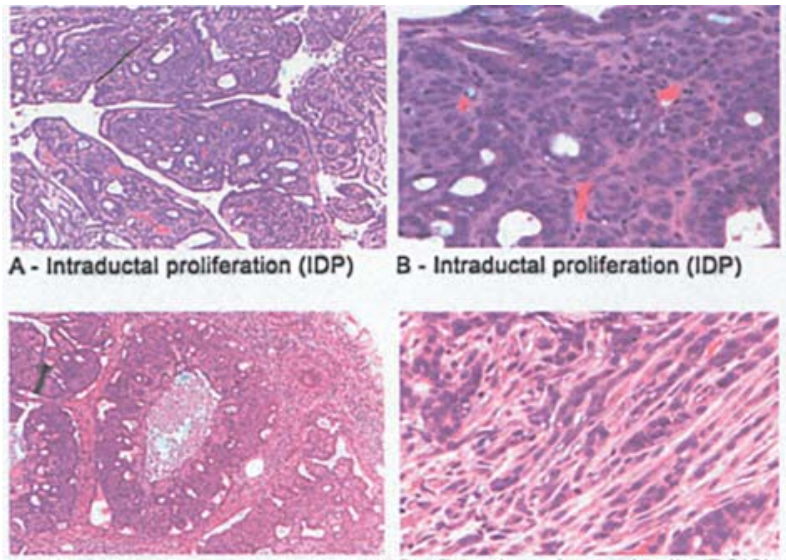

C - Ductal carcinoma in situ (DCIS) D - Ductal carcinoma in situ (DCIS)

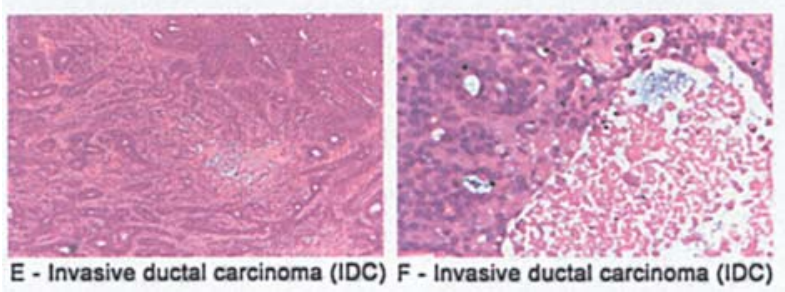

Figure 2. Mammary tumor histology. (a) Intraductal proliferation (intraductal papilloma). Original magnification, x40. (b) Higher magnification of panel a. Original magnification, x200. (c) Ductal carcinoma in situ. Original magnification, $x 40$. (d) Higher magnification shows a proliferation of uniform neoplastic cells with high $\mathrm{N} / \mathrm{C}$ ratio within ductal structures. Original magnification, x200. (e) Invasive ductal carcinoma, arrow shows tumor necrosis in lower left corner. Original magnification, $x 40$. (f) Higher magnification shows neoplastic cells diffusely infiltrating the stroma. Original magnification, x200.

\section{Results}

Body and organ weights. The average body weights (mean \pm standard error) are shown in Table I and Fig. 1a. The L/O and $\mathrm{O} / \mathrm{O}$ rats gained significantly more weight $(\mathrm{P}<0.001)$ than $\mathrm{L} / \mathrm{S}$ and $\mathrm{O} / \mathrm{S}$ rats. Obesity was associated with a significant $(\mathrm{P}<0.001)$ increase in absolute liver weights as well as relative liver weights, expressed as a percentage of body weight in both sham-operated and ovariectomized rats. However, ovariectomy was associated with a significant decrease in both absolute and relative liver weight compared to intact rats $(\mathrm{P}<0.001)($ Table $\mathrm{I})$.

Time course for tumor formation, latency and multiplicity. The time course of palpable mammary tumor detection is shown in Fig. 1b, and data are presented in Table II. The tumor latency (the number of days after DMBA treatment until detection of the first mammary tumor) in the O/S group was 62 days, compared to 73 days in the L/S group and 101 days in $\mathrm{O} / \mathrm{O}$ rats. No mammary tumors were detected in the $\mathrm{L} / \mathrm{S}$ group during the course of this experiment. Tumor latency was shorter in the $\mathrm{O} / \mathrm{S}$ group by 11 days when compared to the L/S group. Moreover, in obese rats, ovariectomy caused a delay of 39 days in tumor latency compared to in $\mathrm{O} / \mathrm{S}$ rats (Table II). Using the day at which $25 \%$ of the rats developed mammary tumors as another marker of mammary tumor latency, $\mathrm{O} / \mathrm{S}$ rats had a shorter latency period of 102 days compared to 134 days for $\mathrm{L} / \mathrm{S}$ rats and 123 days for $\mathrm{O} / \mathrm{O}$ rats. 
Table II. Characteristics of DMBA-induced mammary tumors in sham and ovariectomized lean and obese Zucker rats.

\begin{tabular}{|c|c|c|c|c|}
\hline & $\mathrm{L} / \mathrm{S}$ & $\mathrm{L} / \mathrm{O}$ & $\mathrm{O} / \mathrm{S}$ & $\mathrm{O} / \mathrm{O}$ \\
\hline \multicolumn{5}{|l|}{ Tumor onset } \\
\hline Day of first tumor ${ }^{\mathrm{a}}$ & 73 & 0 & 62 & 101 \\
\hline Day at $25 \%$ tumors $^{\mathrm{b}}$ & 134 & 0 & 102 & 123 \\
\hline \multicolumn{5}{|l|}{ Tumor incidence } \\
\hline$\%$ of rats with tumors ${ }^{c}$ & 30 & 0 & 59 & 36 \\
\hline Multiplicity ${ }^{\mathrm{d}}$ & $1(1-4)$ & 0 & $1(1-4)$ & $1(1-3)$ \\
\hline Tumor weight $(\mathrm{g})^{\mathrm{e}}$ & $0.46(0.1-9.78)$ & 0 & $0.30(0.1-7.94)$ & $0.35(0.1-1.79)$ \\
\hline \multicolumn{5}{|l|}{ Rats with tumors ${ }^{\mathrm{f}}$} \\
\hline IDP & 1 & 0 & 1 & 2 \\
\hline DCIS & 1 & 0 & 7 & 4 \\
\hline IDC & 7 & 0 & 5 & 0 \\
\hline Total tumors $(42)^{g}$ & $13(31 \%)$ & 0 & $20(48 \%)$ & $9(21 \%)$ \\
\hline IDP & $1(7 \%)$ & $0(0 \%)$ & $2(15 \%)$ & $4(44 \%)$ \\
\hline DCIS & $4(31 \%)$ & $0(0 \%)$ & $7(35 \%)$ & $5(56 \%)$ \\
\hline IDC & $8(62 \%)$ & $0(0 \%)$ & $11(55 \%)$ & $0(0 \%)$ \\
\hline
\end{tabular}

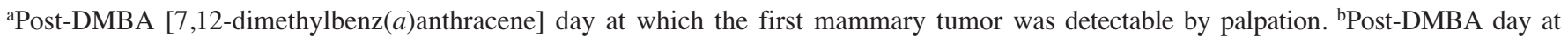

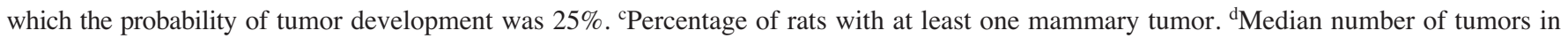
tumor bearing rats (minimum and maximum in parentheses). ${ }^{\mathrm{e}}$ Median tumor weight (minimum and maximum in parentheses) for tumor bearing rats. ${ }^{\mathrm{f}}$ Number of rats with at least one tumor graded as intraductal proliferation (IDP), ductal carcinoma in situ (DCIS), or invasive ductal and lobular carcinoma (IDC) as described in the Materials and methods. ${ }^{\text {gNumber }}$ and percentage of total mammary tumors graded as IDP, DCIS, or IDC as described in the Materials and methods.

At the end of the experiment, 59\% of $\mathrm{O} / \mathrm{S}$ rats developed mammary tumors compared to $30 \%$ of the $\mathrm{L} / \mathrm{S}$ rats $(\mathrm{P}<0.05$, Fig. 1b). However, $36 \%$ of the $\mathrm{O} / \mathrm{O}$ rats developed mammary tumors while no tumors were detected in $\mathrm{L} / \mathrm{S}$ rats $(\mathrm{P}<0.001)$. The $\mathrm{O} / \mathrm{S}$ rats had a higher incidence of mammary tumor development than $\mathrm{O} / \mathrm{O}$ rats $(59 \%$ versus $36 \%)(\mathrm{P}=0.086)$. The tumor multiplicity (median number of mammary tumors per tumor-bearing rat) was not significantly affected in either $\mathrm{O} / \mathrm{S}$ or L/S rats (median, 1 tumor/rat; range, 1-4 tumors/rat) (Table II). Also, we evaluated tumor multiplicity at three time points (73, 104 and 135 days post-DMBA treatment) and the results are shown in Fig. 1c. At each of these time points, the $\mathrm{O} / \mathrm{S}$ group consistently had more mammary tumors and more rats with at least with one tumor compared with other groups. However, tumor multiplicity for the L/S and $\mathrm{O} / \mathrm{O}$ groups was similar during these time points. These results indicate for the first time that mammary tumors can be induced by DMBA in obese Zucker rats in the absence of ovarian estrogens in contrast to the lack of mammary tumor development in $\mathrm{L} / \mathrm{O}$ Zucker rats.

Mammary tumor histology. Mammary tumor histology is presented in Table II. Nine rats in the L/S group, 13 rats in the $\mathrm{O} / \mathrm{S}$ group and six rats in the $\mathrm{O} / \mathrm{O}$ group developed mammary tumors. Within the L/S group, one rat had at least one tumor graded as intraductal proliferation (IDP) while no other groups developed IDP graded tumors. One rat in the L/S group, seven rats in the $\mathrm{O} / \mathrm{S}$ group and four in the $\mathrm{O} / \mathrm{O}$ group had at least one tumor graded as ductal carcinoma in situ (DCIS). Seven rats in the $\mathrm{L} / \mathrm{S}$ group and five rats in the $\mathrm{O} / \mathrm{S}$ group had at least one tumor graded as IDC. A total of 42 mammary tumors were detected in the study, 13 tumors ( $31 \%$ of the total tumors) were detected in the L/S group compared to 20 tumors (48\% of the total tumors) in the O/S group and 9 tumors (21\% of the total tumors) in the $\mathrm{O} / \mathrm{O}$ group. Pathology analyses of these tumors revealed that in the L/S group, 1 of $13(7 \%)$ tumors was graded as IDP, 4 tumors $(31 \%)$ were graded as DCIS and 8 tumors $(62 \%)$ were graded as IDC. Mammary tumors in the $\mathrm{O} / \mathrm{S}$ group included two tumors graded as IDP, seven tumors graded as DCIS (35\%) and 11 tumors graded as IDC $(55 \%)$. In the O/O group, four IDP tumors (44\%) and five DCIS-grade tumors (56\%) were detected (Table II). Obesity was associated with a non-significant increase in tumor weight.

\section{Discussion}

Obesity has been recognized as a risk factor for breast cancer development in postmenopausal women. The increase in risk for obese postmenopausal women has been attributed to increased estrogen exposure due to the high levels of aromatase expression in peripheral adipose tissue. In order to determine whether other sources of estrogen such as adipose tissue, may promote the development of mammary tumors in the DMBA model, we compared the rate of mammary tumor induction in 
ovariectomized and sham-operated lean and obese Zucker rats. We found that DMBA was able to induce mammary tumors in $\mathrm{O} / \mathrm{O}$ Zucker rats in the absence of ovarian estrogen, while $\mathrm{L} / \mathrm{O}$ rats were resistant to DMBA treatment and did not develop mammary tumors. As we reported previously, the obese intact animals had the highest incidence of DMBAinduced mammary tumors (31). This result was expected, since these rats are exposed to estrogen from both ovarian and peripheral estrogen sources. We hypothesize that estrogen from adipose tissue may be sufficient for the development of mammary tumors in the absence of ovarian estrogen.

Our present study confirms that obesity is a major risk factor for mammary tumor development in the DMBA-induced Zucker rat model of mammary carcinogenesis. Furthermore, we have developed a new animal model to study the induction of mammary tumors in $\mathrm{O} / \mathrm{O}$ rats. We believe that mammary tumorigenesis in $\mathrm{O} / \mathrm{O}$ Zucker rats mimics the conditions that are present in obese postmenopausal women. These conditions include a lack of gonadal estrogen and aromatization of androgens to estrogen in adipose tissue as the major source of estrogen.

DMBA-induced mammary tumor induction has been widely used as a model for human breast cancer. The DMBAinduced mammary tumors are dependent on estrogen for development and growth (38-43). Estrogen is a necessary factor for the induction of mammary tumors by DMBA $(41,43-45)$. The fact that $\mathrm{O} / \mathrm{O}$, but not $\mathrm{L} / \mathrm{O}$ rats are susceptible to DMBA-induction of mammary tumors strongly implicates adipose tissue as the source for the estrogen necessary for tumor induction in the absence of ovarian estrogen. These data demonstrate for the first time the development of mammary tumors in the absence of gonadal estrogen using the obese Zucker rat model.

Several epidemiological and experimental animal studies have shown that lifetime exposure to estrogen can increase breast cancer risk $(13,14)$. Obese postmenopausal women have higher circulating estrogen levels than lean post-menopausal women, which can promote breast cancer development. It has been shown that most estrogen in postmenopausal women is produced in peripheral adipose tissue by aromatization of androstenedione to estrone $(46,47)$, especially in obese and overweight women. Studies by MacDonald et al (47-50) demonstrate that the rate of conversion of androstenedione to estrone is increased by obesity. Another factor associated with obesity is low levels of sex hormone binding globulin which results in increased bioavailable estradiol (51). In postmenopausal women, two sources of estrogens can contribute to breast cancer development. The estrogen synthesized in adipose tissue and skin reaches breast tissue through the circulation by an endocrine mechanism, while estrogen produced locally in breast tissue acts by paracrine or intracrine mechanisms to significantly increase local estrogen concentrations.

Several possible explanations for the increased breast cancer risk in postmenopausal women have been postulated; some mechanisms include the involvement of estrogens and androgens, leptin, insulin, insulin-like growth factor (IGF-1) and the aromatization of androgen to estrogens in adipose tissues.

Circulating leptin increases as body weight and fat mass increase $(52,53)$ which may be another contributing factor for breast cancer development in obese postmenopausal women and obese ovariectomized Zucker rats. Previous data suggest that serum leptin may play an important role in the promotion of breast cancer $(18,54,55)$. Leptin, which is a protein product of the $o b$ gene, is expressed primarily in adipose tissue with activity in other tissues such as breast tissue (56). In other animal models, leptin has been found to increase estrogen levels in mammary tissues which can induce proliferation of normal and malignant mammary cells (57). Obese Zucker rats have increased circulating leptin levels that result from a leptin receptor mutation (58). Increased aromatase activity contributes to increased estrogen synthesis in adipose and breast tissues and may be an important factor in increased mammary tumor susceptibility in $\mathrm{O} / \mathrm{O}$ Zucker rats.

Higher insulin levels are also associated with obesity and may enhance cellular proliferation leading to development of breast cancer (15). A related protein, IGF-I, functions as a growth factor for mammary epithelial and tumor cells and increases in the circulation as body mass increases. Recently, several epidemiological studies (59-63) have shown that women with elevated blood concentrations of IGF-I have an increased risk of breast cancer.

Animal models have shown an association between serum IGF-I concentrations and mammary cancer risk. For example, LID mice, which have hepatic IGF-1 gene deletion, have a $75 \%$ reduction in serum IGF-I levels but exhibit normal growth and development (64). Also, these mice have shown a delay in onset of chemically and genetically induced mammary tumors (65). We recently reported a significant increase in circulating IGF-1 levels in obese Zucker rats compared to lean littermates (66). This increased level may contribute to the mammary tumor induction that we observed in our obese Zucker rat model.

Other animal models have been used to investigate the association of body weight with increased incidence of both spontaneous and chemically induced mammary tumors in the presence of gonadal estrogen $(20,22,23,67)$. Some studies used obese intact animal models such as the leptin-deficient (MMTV-TGF- $\alpha / L e p^{o b} L e p^{o b}$ ) mouse model or the leptin receptor-deficient mouse model (MMTV-TGF- $\alpha /$ Lepr $^{d b}$ Lepr $^{d b}$ ). However, the obese animals in these studies failed to develop mammary tumors $(68,69)$.

The present study used the DMBA-induced mammary tumor model to investigate whether the increased adipose tissue in $\mathrm{O} / \mathrm{O}$ animals would promote development of mammary tumors. To our knowledge, this study is the first to report that obesity can promote DMBA-induced mammary tumor induction in obese Zucker rats in the absence of ovarian estrogen. We hypothesize that estrogen production in adipose tissue is sufficient to promote mammary tumor development in the DMBA-induced Zucker rat model. The underlying mechanism for this observation is currently under investigation in our laboratory.

\section{Acknowledgments}

This study was supported by a grant from the Susan G. Komen Foundation. The authors wish to thank Phaedra Yount and John Gregan for valuable assistance in preparation of this manuscript. 


\section{References}

1. Anonymous: NHLBI Obesity Education Initiative Expert Panel. Obesity Res 6: 51S, 1998.

2. Mokdad AH, Bowman BA, Ford ES, Vinicor F, Marks JS and Koplan JP: The continuing epidemics of obesity and diabetes in the United States. JAMA 286: 1195-1200, 2001

3. Mokdad AH, Ford ES, Bowman BA, Dietz WH, Vinicor F, Bales VS and Marks JS: Prevalence of obesity, diabetes, and obesity-related health risk factors, 2001. JAMA 289: 76-79, 2003.

4. International Agency for Research on Cancer: Weight Control and Physical Activity. IARC Press, Lyon, 2002.

5. American Cancer Society: What Are the Key Statistics for Breast Cancer? American Cancer Society, Atlanta, 2006.

6. Calle EE, Rodriguez C, Walker-Thurmond $\mathrm{K}$ and Thun MJ: Overweight, obesity, and mortality from cancer in a prospectively studied cohort of U.S. adults. N Engl J Med 348: 1625-1638, 2003.

7. Trock BJ: Breast cancer in African American women: epidemiology and tumor biology. Breast Cancer Res Treat 40: 11-24, 1996.

8. Bernstein L, Teal CR, Joslyn S and Wilson J: Ethnicity-related variation in breast cancer risk factors. Cancer 97 (suppl 1): 222-229, 2003.

9. Whittemore AS, Paffenbarger RS Jr, Anderson K and Lee JE: Early precursors of site-specific cancers in college men and women. J Natl Cancer Inst 74: 43-51, 1985.

10. Hankinson SE, Willett WC, Manson JE, et al: Alcohol, height, and adiposity in relation to estrogen and prolactin levels in postmenopausal women. J Natl Cancer Inst 87: 1297-1302, 1995.

11. Rapp K, Schroeder J, Klenk J, et al: Obesity and incidence of cancer: a large cohort study of over 145,000 adults in Austria. Br J Cancer 93: 1062-1067, 2005.

12. Edman CD, Aiman EJ, Porter JC and MacDonald PC: Identification of the estrogen product of extraglandular aromatization of plasma androstenedione. Am J Obstet Gynecol 130: 439-447, 1978.

13. Cauley JA, Lucas FL, Kuller LH, Stone K, Browner W and Cummings SR: Elevated serum estradiol and testosterone concentrations are associated with a high risk for breast cancer. Study of Osteoporotic Fractures Research Group. Ann Intern Med 130: 270-277, 1999.

14. Key T, Appleby P and Reeves G: Endogenous sex hormones and breast cancer in postmenopausal women: reanalysis of nine prospecive studies. J Natl Cancer Inst 94: 606-616, 2002.

15. Bruning PF, Bonfrer JM, van Noord PA, Hart AA, de JongBakker $\mathrm{M}$ and WJ Nooijen: Insulin resistance and breast-cancer risk. Int J Cancer 52: 511-516, 1992.

16. Sinha MK, Opentanova I, Ohannesian JP, et al: Evidence of free and bound leptin in human circulation. Studies in lean and obese subjects and during short-term fasting. J Clin Invest 98 : 1277-1282, 1996 .

17. McGregor GP, Desaga JF, Ehlenz K, et al: Radioimmunological measurement of leptin in plasma of obese and diabetic human subjects. Endocrinology 137: 1501-1504, 1996.

18. Okumura M, Yamamoto M, Sakuma H, et al: Leptin and high glucose stimulate cell proliferation in MCF-7 human breast cancer cells: reciprocal involvement of PKC-alpha and PPAR expression. Biochim Biophys Acta 1592: 107-116, 2002.

19. Rose DP, Gilhooly EM and Nixon DW: Adverse effects of obesity on breast cancer prognosis, and the biological actions of leptin (review). Int J Oncol 21: 1285-1292, 2002.

20. Waxler SH, Tabar P and Melcher LR: Obesity and the time of appearance of spontaneous mammary carcinoma in $\mathrm{C} 3 \mathrm{H}$ mice. Cancer Res 13: 276-278, 1953.

21. Waxler SH: The relationship of obesity to liver tumors in mice. Stanford Med Bull 18: 1-4, 1960.

22. Haseman JK, Bourbina J and Eustis SL: Effect of individual housing and other experimental design factors on tumor incidence in B6C3F1 mice. Fundam Appl Toxicol 23: 44-52, 1994.

23. Wolff GL, Kodell RL, Cameron AM and Medina D: Accelerated appearance of chemically induced mammary carcinomas in obese yellow (Avy/A) (BALB/c X VY) F1 hybrid mice. J Toxicol Environ Health 10: 131-142, 1982.

24. Zucker L and Zucker T: Fatty, a new mutation in the rat. J Hered 52: 275-278, 1961.

25. Zucker TF and Zucker LM: Fat accretion and growth in the rat. J Nutr 80: 6-19, 1963.
26. Chua SC Jr, White DW, Wu-Peng XS, et al: Phenotype of fatty due to Gln269Pro mutation in the leptin receptor (Lepr). Diabetes 45: 1141-1143, 1996.

27. Chua SC Jr, Chung WK, Wu-Peng XS, Zhang Y, Liu SM, Tartaglia L and Leibel RL: Phenotypes of mouse diabetes and rat fatty due to mutations in the $\mathrm{OB}$ (leptin) receptor. Science 271: 994-996, 1996.

28. Bray GA, York DA and Fisler JS: Experimental obesity: a homeostatic failure due to defective nutrient stimulation of the sympathetic nervous system. Vitam Horm 45: 1-125, 1989.

29. Bray GA: The Zucker-fatty rat: a review. Fed Proc 36: 148-153, 1977.

30. de Assis S, Wang M, Goel S, Foxworth A, Helferich W and Hilakivi-Clarke L: Excessive weight gain during pregnancy increases carcinogen-induced mammary tumorigenesis in Sprague-Dawley and lean and obese Zucker rats. J Nutr 136: 998-1004, 2006.

31. Hakkak R, Holley AW, MacLeod SL, et al: Obesity promotes 7,12-dimethylbenz(a)anthracene-induced mammary tumor development in female Zucker rats. Breast Cancer Res 7: R627-R633, 2005.

32. Hakkak R, Korourian S, Shelnutt S, Lensing S, Ronis M and Badger T: Diets containing whey proteins or soy protein isolate protect against 7,12-dimethylbenz(a)anthracene-induced mammary tumors in female rats. Cancer Epidemiol Biomarkers Prev 9: 113-117, 2000.

33. Altman D: Pratical Statistics for Medical Research. Chapman and Hall, London, 1991.

34. Cox D and Oakes D: Analysis of Survival Data. Chapman and Hall, London, 1894.

35. Gross A and Clark V: Survival distribution: Reliability Applications in Biomedical Sciences. Wiley, New York, 1975.

36. Bhattacharyya GK and Johnson RA: Statistical Concepts and Methods. Wiley, New York, 1977.

37. Kruskal W and Wallis W: Use of ranks in one-criterion variance analysis. J Am Stat Assoc 47: 583-621, 1952.

38. Asselin J, Kelly PA, Caron MG and Labrie F: Control of hormone receptor levels and growth of 7,12-dimethylbenz(a)anthraceneinduced mammary tumors by estrogens, progesterone and prolactin. Endocrinology 101: 666-671, 1977

39. Asselin $\mathrm{J}$ and Labrie F: Effects of estradiol and prolactin on steroid receptor levels in 7,12-dimethylbenz(a)anthracene-induced mammary tumors and uterus in the rat. J Steroid Biochem 9: 1079-1082, 1978.

40. Dauvois S, Li SM, Martel C and Labrie F: Inhibitory effect of androgens on DMBA-induced mammary carcinoma in the rat. Breast Cancer Res Treat 14: 299-306, 1989.

41. Huggins C, Grand LC and Brillantes FP: Mammary cancer induced by a single feeding of polymucular hydrocarbons, and its suppression. Nature 189: 204-207, 1961.

42. Sasaki GH and Leung BS: On the mechanism of hormone action in 7,12 dimethylbenz(a)anthracene-induced mammary tumor. I. Prolactin and progesterone effects on estrogen receptor in vitro. Cancer 35: 645-651, 1975.

43. Leung BS, Sasaki GH and Leung JS: Estrogen-prolactin dependency in 7,12-dimethylbenz(a)anthracene-induced tumors. Cancer Res 35: 621-627, 1975.

44. Dao TL: The role of ovarian hormones in initiating the induction of mammary cancer in rats by polynuclear hydrocarbons. Cancer Res 22: 973-981, 1962.

45. Welsch CW: Host factors affecting the growth of carcinogeninduced rat mammary carcinomas: a review and tribute to Charles Brenton Huggins. Cancer Res 45: 3415-3443, 1985.

46. Endogenous Hormones and Breast Cancer Collaborative Group: Body mass index, serum sex hormones and breast cancer risk in postmenopausal women. J Natl Cancer Inst 95: 1218-1226, 2003.

47. Grodin JM, Siiteri PK and MacDonald PC: Source of estrogen production in postmenopausal women. J Clin Endocrinol Metab 36: 207-214, 1973.

48. MacDonald PC, Edman CD, Hemsell DL, Porter JC and Siiteri PK: Effect of obesity on conversion of plasma androstenedione to estrone in postmenopausal women with and without endometrial cancer. Am J Obstet Gynecol 130: 448-455, 1978.

49. MacDonald PC, Madden JD, Brenner PF, Wilson JD and Siiteri PK: Origin of estrogen in normal men and in women with testicular feminization. J Clin Endocrinol Metab 49: 905-916, 1979. 
50. Hemsell DL, Grodin JM, Brenner PF, Siiteri PK and MacDonald PC: Plasma precursors of estrogen. II. Correlation of the extent of conversion of plasma androstenedione to estrone with age. J Clin Endocrinol Metab 38: 476-479, 1974.

51. Kaaks R, Rinaldi S, Key TJ, et al: Postmenopausal serum androgens, oestrogens and breast cancer risk: the European prospective investigation into cancer and nutrition. Endocr Relat Cancer 12: 1071-1082, 2005.

52. Fung TT, Rimm EB, Spiegelman D, Rifai N, Tofler GH, Willett WC and Hu FB: Association between dietary patterns and plasma biomarkers of obesity and cardiovascular disease risk. Am J Clin Nutr 73: 61-67, 2001.

53. Maffei M, Halaas J, Ravussin E, et al: Leptin levels in human and rodent: measurement of plasma leptin and ob RNA in obese and weight-reduced subjects. Nat Med 1: 1155-1161, 1995.

54. O'Brien SN, Welter BH and Price TM: Presence of leptin in breast cell lines and breast tumors. Biochem Biophys Res Commun 259: 695-698, 1999.

55. Dieudonne MN, Machinal-Quelin F, Serazin-Leroy V Leneveu MC, Pecquery R and Giudicelli Y: Leptin mediates a proliferative response in human MCF7 breast cancer cells. Biochem Biophys Res Commun 293: 622-628, 2002.

56. Zhang Y, Proenca R, Maffei M, Barone M, Leopold L and Friedman JM: Positional cloning of the mouse obese gene and its human homologue. Nature 372: 425-432, 1994.

57. Hu X, Juneja SC, Maihle NJ and Cleary MP: Leptin - a growth factor in normal and malignant breast cells and for normal mammary gland development. J Natl Cancer Inst 94: 1704-1711, 2002.

58. Phillips MS, Liu Q, Hammond HA, Dugan V, Hey PJ, Caskey CJ and Hess JF: Leptin receptor missense mutation in the fatty Zucker rat. Nat Genet 13: 18-19, 1996.

59. Hankinson SE, Willett WC, Colditz GA, et al: Circulating concentrations of insulin-like growth factor-I and risk of breast cancer. Lancet 351: 1393-1396, 1998.
60. Toniolo P, Bruning PF, Akhmedkhanov A, et al: Serum insulinlike growth factor-I and breast cancer. Int J Cancer 88: 828-832, 2000.

61. Muti P, Quattrin T, Grant BJ, et al: Fasting glucose is a risk factor for breast cancer: a prospective study. Cancer Epidemiol Biomarkers Prev 11: 1361-1368, 2002.

62. Krajcik RA, Borofsky ND, Massardo S and Orentreich N: Insulin-like growth factor I (IGF-I), IGF-binding proteins, and breast cancer. Cancer Epidemiol Biomarkers Prev 11: 1566-1573, 2002.

63. Borofsky ND, Vogelman JH, Krajcik RA and Orentreich N: Utility of insulin-like growth factor-1 as a biomarker in epidemiologic studies. Clin Chem 48: 2248-2251, 2002.

64. Yakar S, Liu JL, Stannard B, Butler A, Accili D, Sauer B and LeRoith D: Normal growth and development in the absence of hepatic insulin-like growth factor I. Proc Natl Acad Sci USA 96: 7324-7329, 1999.

65. Wu Y, Cui K, Miyoshi K, et al: Reduced circulating insulin-like growth factor I levels delay the onset of chemically and genetically induced mammary tumors. Cancer Res 63: 4384-4388, 2003.

66. Hakkak R, Holley A, Bunn R, Winters A and MacLeod S: Effects of obesity on serum Insulin Growth Factor 1 (IGF-1) levels in lean and obese female Zucker rats following DMBA treatment. FASEB J 19: A993, 2005.

67. Waxler S: Obesity and cancer susceptibility in mice. Am J Clin Nutr 8: 760-766, 1960.

68. Cleary MP, Phillips FC, Getzin SC, et al: Genetically obese MMTV-TGF-alpha/Lep(ob)Lep(ob) female mice do not develop mammary tumors. Breast Cancer Res Treat 77: 205-215, 2003.

69. Cleary MP, Juneja SC, Phillips FC, Hu X, Grande JP and Maihle NJ: Leptin receptor-deficient MMTV-TGF-alpha/ Lepr(db)Lepr(db) female mice do not develop oncogene-induced mammary tumors. Exp Biol Med 229: 182-193, 2004. 